\title{
Recenze knihy Sokolíčková, z. (ed.): Kyber a eko. Digitální technologie $v$ environmentálních souvislostech
}

\section{Jana Dlouhá}

\author{
Envigogika 14 (2) - Recenze / Reviews
}

Publikováno / Published 30. 12. 2019

\section{DOI : $10.14712 / 18023061.602$}

Koncem roku 2019 vyšel v nakladatelství Host zajímavý soubor příspěvků k tématu eko- v souvislostech technologie (či obráceně) z pera významných myslitelů i představitelů alternativní kultury. Kniha vznikla na mezioborovém půdorysu, a její spoluautoři vyprávějí každý jiný příběh, který je však překvapivě konzistentní - a to přesto, že se liší nejen profesní background jednotlivých autorů, jejich téma, ale i žánr a styl vyprávění. Celek je totiž dobrým př́kladem mezioborového dialogu, kdy se jeho účastníci sejdou "u jedné věci" a představí své různorodé pohledy, které ji osvětlí z rưzných stran. Protože měli předtím možnost se sejít fyzicky (všichni byli řečníky konference Naše společná přítomnost 2018), a své názory navzájem vyposlechnout, jedná se často o kritický dialog, kdy autoři polemizují a své závěry si vzájemně zpochybňují.

Toto jiskření probíhá mezi Manfredem Spitzerem a Václavem Bělohradským - první shromažd'uje argumenty na podporu své teze o škodlivosti digitálních technologií, druhý hledá cesty a možnosti pokroku ve stávajícím rozvrhu světa. Oba přinášejí překvapivé informace či názory, Manfred Spitzer dokonce velmi systematicky mapuje „terén“ lidské psychologie a fyziologie - hledá dopady, které budou mít moderní technologie na to, co se ve vědeckém světě pokládá za povahu lidskosti. $V$ tomto případě je však třeba říci, že obrovské množství citací dokládající závěry není vždy zcela přesvědčivé a čtenář by uvítal kritický „pohled z druhé strany" nebo alespoň popis podmínek, za kterých tyto závěry platí. (Manfred Spitzer v duchu své tvorby z posledních let píše o tom, co přináší Smartphonová pandemie / Rizika a vedlejší účinky používání digitálních informačních technologii z hlediska zdraví, vzdělání a společnosti; také Václav Bělohradský vystupuje ze svého myšlenkového okruhu jen mírně, přináší téma Demokracie a názory v éře postkatechistických většin.)

Martin Leskovjan (Decentralizace, kryptotechnologie a jejich dopad na politické rízení a řešení environmentálních problémů) je fascinován možnostmi digitálních technologií, které zcela jistě přinesou změny srovnatelné s jinými převratnými událostmi lidských dějin, například nástupem knihtisku. Tehdy se každý člověk mohl stát čtenářem, dnes zase může být „spisovatelem“ s nezanedbatelným vlivem na společenské dění. Současně ovšem budou na lidstvo působit velké, často nevratné změny přírodního prostředí; je tak otázkou, zda strategie „nápravy škod" a případného návratu do stavu před poškozením je ještě na pořadu dne. Co se dá dělat za tímto "bodem zvratu”, k tomu nás vývoj v oblasti technologií může inspirovat, nebo přinejmenším poskytnout prostředí pro experimentování s alternativami. Tak by se mohla objevit i nějaká forma sebeobrany proti nastupující absolutní nutnosti, tentokrát ne přírodní, ale technologické...

Text Jeremiáše Havranu Vize pastevecké budoucnosti / Možnosti pastorální rezistence v době technologické singularity posunuje téma do polohy vizionářské - zde se zdá, že fantazie není o nic méně reálná, než fakta; obsahuje pravdy, které nelze dokázat detektivními postupy vědy, přesto vycházejí z generacemi ověřených zkušeností a jsou „pravdivé“ tím, 
že se člověka bytostně dotýkají. Kde Spitzer spoléhá na čísla a důkazy, a Leskovjan se oddává čisté spekulaci (byt́ podložené anarchistickou zkušeností), tam Havranu útočí na mysl pomocí predstav, pocitů a zkušenosti. Navozuje tak atmosféru strachu, který je v jeho apokalyptické vizi všudypř́tomný; současně se však snaží najít skuliny, ve kterých Ize přežít a zůstat sám sebou. At již prožívá skutečnost $v$ jisté nadsázce, nebo popisuje specifickou zkušenost určité minoritní komunity, snaží se vystopovat možnosti, které zbývají pro ty, kdo ji chtějí prožívat opravdově, zůstávat ve spojení s určitým typem moudrosti, která neztratila spojení s minulostí a konstitutivními východisky lidského světa. Zjištujujeme tak, že mnoho možností pro tento typ existence nezbývá - a my se musíme naučit guerillové taktice, pro kterou zde autor otevírá prostory.

Vyjímečné jsou i další dva příspěvky - text Jany Karlové Digitální domovy a města tím, že jeho úvahy vycházejí z myšlenek širokého spektru současných autorů. S nimi autorka dovede pracovat tak, že pro své každodenní zkušenosti a setkání najednou nacházíme vysvětlení, o nichž jsme dříve neuvažovali. Tohoto spojení teoretického a zkušenostního poznání je těžké dosáhnou a obě složky náležitě vyvážit; zde je to předvedeno s hlubším vhledem a navíc velmi krásným jazykem. Poslední příspěvek Martina Soukupa a Jana D. Bláhy Od tužky k mobilu: vnímání moderních technologií v papuánské vesnici pak je zajímavý svou exotičností: tím, že představuje unikátní přiběhy lidí, kteří se právě probouzejí z pravěku do nejmodernějšího světa. $Z$ formálního hlediska však právě tento text má jisté nedostatky od prostého popisu př́běhů, které autoři sami zažili, se př́liš k teoretické reflexi neposunul, a navíc místy pưsobí poněkud zmateným dojmem. Nicméně do tohoto souboru patří a symbolicky jej uvozuje: my všichni se každé ráno probouzíme do světa, o kterém nic nevíme a musíme teprve složitě zjištovat, co se dá v tomto novém kontextu vůbec dělat. Kdybychom neměli možnost si to uvědomit (nad podobnými texty, jaké přináší kniha editovaná Zdenkou Sokolíčkovou), nezbylo by nám než se novým skutečnostem s jejich pravidly podvolit - a to s sebou nese významná rizika, která si dosud plně neuvědomujeme.

V tomto ohledu je cenný doslov Marka Orko Váchy, který připomíná význam spirituální dimenze - pozapomněli jsme na ni (trochu i v tomto souboru), a přece je to právě ona, co by mohlo naši civilizaci ochránit nebo snad i nakonec zachránit. Jeho závěrečné slovo je krátké, ale podstatné - $v$ tom je podobné úvodnímu textu Zdenky Sokoličkové. Editorce se $v$ tomto souboru tak trochu podařilo nemožné: zachytit překotnou povahu doby, kdy se hroutí téměř všechny tradiční představy o světě i povaze lidskosti, a na jejich místo se prosazují neskutečné vize, které jsme dosud potkávali jen při čtení science fiction. Dokázala také $z$ tohoto všeobecného zmatení vytěžit obecné principy a poučení, jimiž nás vede $k$ přemýšlení o tom, zda a jak mohou tyto změny ovlivnit povahu člověka. Již ne obecně, ale konkrétně - mne nebo vás, prostě toho, kdo se do čtení knihy pustil a vzal ji vážně. Což určitě stojí za to.

\section{Literatura:}

- Sokolíčková, Z. (ed.) (2019): Kyber a eko. Digitální technologie v environmentálních souvislostech, Host, Brno, ISBN 978-80-7577-613-6 